Department of Haematology, St. Thomas's Hospital Medical School, London.

Fourth Year fellowship: Dr. G. F. Rowland, to continue a study of the mechanism of carcinogenesis induced by $p$-dimethylaminoazobenzene, at the Department of Chemical Pathology, University College Hospital Medical School, London.

Prof. Bernard Katz (University College, London) was appointed to the Advisory Board in succession to Sir Lindor Brown (University of Oxford) who retired after 12 years service.

\section{University and College News:}

\section{Battersea College of Technology}

Dr. J. M. ZAREK, reader in engineering science at King's College, London, has been appointed professor and head of the Department of Mechanical Engineering.

Churchill College, Cambridge

Honorary Fellowships have been conferred on the following : Mr. R. Churchill, Dr. F. Crick, Mr. H. Moore and Dr. B. Wallis.

Glasgow

DR. H. G. Morgan, senior lecturer in pathology in the University of St. Andrews, has been appointed to the new chair of pathological biochemistry.

Leeds

The following lecturers have been appointed : Dr. G. Brooke (physics); Mr. J. E. Rubio (electrical and electronic engineering); Mr. P. Sunderland (chemical engineering); Mr. L. A. Walker (civil engineering).

Nottingham

Dr. A. J. M. SPEncer, reader and acting head of department, has been appointed professor and head of the Department of Theoretical Mechanies.

Swansea

Mr. C. E. M. Hansel, senior lecturer in psyehology at the University of Manchester, has been appointed to the newly established chair of psychology. The following lecturers have also been appointed: Dr. R. Phythian and Dr. J. T. Davies (physics); Dr. C. J. Ridler-Rowe (pure mathematics); Dr. D. T. Herbert (geography); Dr. R. A. E. Tilney-Bassett (genetics in the Department of Zoology); Dr. J. S. Ryland (marine biology in the Department of Zoology); Mr. J. C. Peters and Dr. Y. K. Cheung (civil engineering); Dr. S. D. Probert (mechanical engineering).

Weish College of Advanced Technology

DR. J. R. BRIstow has been appointed to the chair of applied physics. Mr. C. T. Baldwin has been appointed to the chair of electrical engineering.

The Night Sky in July

FuLL moon occurs on July 13 d 17 h U.T. and new moon on July 28d. 12. The following conjunctions with the Moon occur: July $4 \mathrm{~d} 21 \mathrm{~h}$, Mars $5^{\circ} \mathrm{S}$.; July $18 \mathrm{~d} 07 \mathrm{~h}$, Saturn $3^{\circ}$ N.; July 25 d 14 h, Jupiter $1^{\circ}$ S.; July $30 d 07 \mathrm{~h}$, Venus $4^{\circ} \mathrm{S}$. Mercury is unfavourably placed for observation during the month. Venus sets at $21 \mathrm{~h} 40 \mathrm{~m}, 21 \mathrm{~h} 25 \mathrm{~m}$, $21 \mathrm{~h} 00 \mathrm{~m}$ on July $1,14,29$, respectively; its stellar magnitude is $-3 \cdot 3$ and its distance from the Earth on July 15 is 140 million miles. Mars sets at $23 \mathrm{~h} 40 \mathrm{~m}, 22 \mathrm{~h} 50 \mathrm{~m}, 22 \mathrm{~h}$ $00 \mathrm{~m}$ at the beginning middle and end of the month, respectively; its stellar magnitude is $+1 \cdot 1$; its distance from the Earth on July 15 is 134 million miles and is in Virgo. Jupiter rises at $2 \mathrm{~h} 15 \mathrm{~m}, 1 \mathrm{~h} 30 \mathrm{~m}, 0 \mathrm{~h} 40 \mathrm{~m}$ at the beginning, middle and end of the month, respectively; its stellar magnitude is -1.6 ; its distance from the Earth on July 15 is 547 million miles and is in Taurus. Saturn rises at $23 \mathrm{~h} 15 \mathrm{~m}, 22 \mathrm{~h} 15 \mathrm{~m}, 21 \mathrm{~h} 20 \mathrm{~m}$ at the beginning, middle and end of the month, respectively; its stellar magnitude is $+1 \cdot 1$; its distance from the Earth on July 15 is 844 million miles and is in Aquarius. The following occultations of stars brighter than magnitude 6 occur, observation being made at Greenwich: July $12 \mathrm{~d}$ $22 \mathrm{~h} 57.4 \mathrm{~m}, \sigma$ Sgr $(R)$; July $22 \mathrm{~d} 01 \mathrm{~h} 33.4 \mathrm{~m}, 64$ Cet $(R)$; July $22 \mathrm{~d} 01 \mathrm{~h} 52 \cdot 0 \mathrm{~m} \xi^{1}$ Cet $(D)$; July $22 \mathrm{~d} 02 \mathrm{~h} 39 \cdot 4 \mathrm{~m}$, $\xi^{1}$ Cet $(R)$. $D$ refers to disappearance and $R$ to reappearance. The $\delta$ Aquarid meteors are active in the period July 15-August 10. Conditions of observation are favourable, with maximum occurring during July 29. The radiant is at $339^{\circ}$ R.A. $-17^{\circ}$ Dec. The Perseid meteors become active after July 27 .

\section{Announcements}

DR. J. TAYLor has been arwarded the Medal of the Society of Chemical Industry for 1965.

Dr. Benjamin Lax, distinguished for his work in the field of solid-state physics, has been appointed professor of physics at the Massachusetts Institute of Technology. $\mathrm{He}$ will continue to serve as director of the Institute's National Magnet Laboratory, but will relinquish his responsibilities as associate director of the Lincoln Laboratory, Lexington.

THE summer courses of the Enrico Fermi International School of Physics, organized by the Società Italiana di Fisica, will be held at Varenna. Three courses will be held as follows: the optical properties of solids (June 28July 10); high-energy astrophysics (July 12-24); manybody description of nuclear structure and reactions (July 26-August 14). Further information can be obtained from Prof. G. Germana, Società Italiana di Fisica, Via Irnerio 46, Bologna.

A CONFERENCE on "Plastics in Building Structures", arranged by the Plastics Institute in association with the Institution of Civil Engineers, the Institution of Structural Engineers and the Royal Institute of British Architects, will be held at the Institute during June 14-16. Further information can be obtained from the Secretary, the Plastics Institute, 6 Mandeville Place, London, W.1.

AN international symposium on "Biochemistry and Physiology of Alkaloids" will be held in Halle/Saale during June 24-27. Further information can be obtained from Prof. K. Mothes, Deutsche Akademie der Wissenschaften zu Berlin, Weinbergweg, Halle/Saale.

THE seventeenth British Electrical Power Convention on "Electricity in the Fuel and Power Future" will be held in Brighton during June 21-24. Further information can be obtained from the Electrical Development Association, Trafalgar Buildings, 1 Charing Cross, London, S.W.1.

Av international meeting on "Fuel Cells", organized by the Société d'Etudes de Recherches et d'Applications pour l'Industrie, will be held in Brussels during June 21-24. Further information can be obtained from Mr. Vanleugenhaghe, c/o the Société d'Etudes de Recherches et d'A.pplications pour l'Industrie, 1091 Chaussée d'Alsemberg, Brussels 18.

A ONE-WEek programme in "Techniques in Oceanographic Instrumentation" will be held at the Massachusetts Institute of Technology during June 21-25. Topics to be discussed will include: navigational aids; the instruments of physical oceanography; the instruments of submarine geology and geophysics; selected topics in chemical and biological oceanography. Further information can be obtained from the Director of the Summer Session, Room E19-356, Massachusetts Institute of Tochnology, Cambridge, Massachusetts.

ERratum. In the article entitled "Drug Resistance and its Transfer in Salmonella typhimurium" by Dr. E. S. Anderson and Dr. M. J. Lewis, which appeared on p. 579 of the May 8, 1965, issue of Nature, p. 582, para. 8, line 15 should read "population from $3.0 \times 10^{8}$ to $1.3 \times 10^{8} \ldots$.." and not "population from $3.0 \times 10^{8}$ to $1.3 \times 10^{4} \ldots$ " as printed. 